\title{
A Comparative Study of Immobilized-Whole Cell and Commercial Lipase as a Biocatalyst for Biodiesel Production from Soybean Oil
}

\author{
S.N. Hashemizadeh ${ }^{1,2}$, O. Tavakoli ${ }^{*}$, F. Tabandeh ${ }^{2}$, A.A. Karkhane ${ }^{2}$, Z. Forghanipour ${ }^{1,2}$ \\ ${ }^{1}$ School of Chemical Engineering, College of Engineering, University of Tehran, 16 Azar Street, Tehran, Iran \\ ${ }^{2}$ Industrial and Environmental Biotechnology Department, National Institute of Genetic Engineering and \\ Biotechnology (NIGEB), Tehran, Iran \\ *Corresponding author. Tel: +98 2161112187 Fax: +98 21 66498984, E-mail: otavakoli@ut.ac.ir
}

\begin{abstract}
Recently, there has been considerable attention in the direct use of intracellular lipase as a whole-cell biocatalyst (indirect immobilization of the enzyme) for biodiesel production since immobilization can be carried out spontaneously during the process of cell cultivation. In this research the ability of Rhizopus oryzae (ATCC 9374) whole-cell biocatalyst that was immobilized within biomass support particles (BSPs) was investigated and compared with Novozym 435 (most effective extracellular immobilized lipase) for methanolysis of soybean oil in solvent free system. The maximum methyl esters content in the reaction mixture reaches $84 \mathrm{wt} \%$ using $R$.oryzae whole-cell biocatalyst in optimum condition $(6 \mathrm{~mm} \times 6 \mathrm{~mm} \times 3 \mathrm{~mm}$ BSPs size, olive oil as carbon sources in basel medium, emulsification using ultrasonicated of reaction mixtures, $15 \mathrm{wt} \%$ water content and $7 \mathrm{wt} \%$ immobilized BSPs, addition of methanol at 0,4 and $18 \mathrm{~h}$ ) and at reaction time of $48 \mathrm{~h}$ which is remarkably comparable with yield of biodiesel at $90 \mathrm{wt} \%$ obtained with Novozym 435 . Both the lipases can be used for repeated batches cycles. These findings indicate that, given the simplicity of the lipase production process and the long-term stability of lipase activity, the use of whole-cell biocatalysts immobilized within BSPs and treated with glutaraldehyde solution suggest a favorable means of biodiesel fuel production for industrial application.
\end{abstract}

Keywords: Biodiesel, Whole-Cell Biocatalyst, Rhizopus oryzae, Novozym 435.

\section{Introduction}

The consideration depletion of fossil resources and increasing social environmental awareness has led to a search for fuels that can be produced from renewable sources such as plant biomass [1]. A number of studies have examined the methods that are promising use of triglycerides (vegetable oils or animal fats) as an alternative fuel for diesel engines. However, the direct use of vegetable oils or oil blends is generally considered impractical because of high viscosity, acid composition and free fatty acid content. Facing these issues, transesterification; also called alcoholysis, were used to reduce viscosity and improve the physical properties of such fuels. Transesterification which has been recently developed to replace oils and fats as renewable energy resources is similar to hydrolysis reaction in which water is substituted with alcohol [2]. Biodiesel is explained as the non-petroleum-based diesel fuel be made up of short chain alkyl (methyl or ethyl) esters, typically made by transesterification of vegetable oils or animal fats, which can be used (alone, or blended with routine petrodiesel) in unchanged diesel-engine vehicles. It is biodegradable and nontoxic, has low discharge profile and so is environmentally advantageous [3]. Transesterification of triacylglycerides can be carried out by different catalytic processes. Alkali catalysis is widely applied for the commercial production of biodiesel fuel. However, enzymatic transesterification using lipase enzymes offers considerable advantages, including reducing process operations in biodiesel fuel production and an easy separation of the glycerol byproduct [4]. There are two major classification of enzymatic biocatalyst: (1) extracellular lipases (i.e. the enzyme has previously been recovered from the live-producing microorganism broth and then purified) which the major producer microorganisms are Mucor miehei, Rhizopus oryzae, Candida Antarctica, Pseudomonas cepacia; and (2) intracellular lipase which remains either inside or in the cell-producing walls which in both cases the 
enzyme is immobilized. The advantage of immobilization in this system is frequent utilization due to its easy recovery from the reaction mixture [5].

Several researchers have reported that the commercially available Candida antarctica lipase immobilized on acrylic resin (Novozym 435) was the most effective lipase between any of the extracellular lipases tested for transesterification reaction of vegetable oils where methanol is used as acyl acceptor [6-8]. Although immobilization of extracellular enzyme seemed to be a common method for enzymatic alcoholysis, it needs complicated methods for separation, purification and stabilization of lipases which in turn increase the process cost in industrial scale [9]. In recent years, there has been considerable interest in the direct use of intracellular lipase as a whole-cell biocatalyst (indirect immobilization of the enzyme) for biodiesel production. Utilizing whole cell overproducing intracellular lipase in which the purification and stabilization of the enzyme are not necessary instead of conventional immobilized lipase for biodiesel production is a potential way to reduce the biocatalyst cost, because immobilization can be carried out spontaneously during the process of cell cultivation [10] In this research the ability of Rhizopus oryzae (ATCC 9374) whole-cell biocatalyst that was immobilized within biomass support particles (BSPs) made of reticulated polyurethane foam was investigated and compared with that of commercially available most effective lipase (Novozym 435) for methanolysis of soybean oil in solvent free system.

\section{Materials and methods}

\subsection{Materials}

Refined soybean oil was purchased from Behshahr Industrial Co. (Tehran, Iran). Commercial immobilized lipase from Candida antarctica, namely Novozym 435 was provided as a gift from Novo Nordisk (A.S., Denmark-Tehran Office).

Rhizopus oryzae ATCC 9374 purchased from PTCC (Persian Type Culture Collection, Tehran, Iran). Palmitic acid methyl ester, stearic acid methyl ester, oleic acid methyl ester, linoleic acid methyl ester, linolenic acid methyl ester were purchased from Sigma and were chromatographically pure. All other chemicals were obtained commercially and were of analytical grade.

\subsection{R. oryzae whole cell biocatalyst preparation}

Whole cell biocatalyst experiments were carried out using R. oryzae ATCC 9374, which has a 1,3-positional specify lipase. The culture medium contains in $1 \mathrm{l}$ tap water (its $\mathrm{pH}$ was initially adjusted to 5.6) were $70 \mathrm{~g}$ polypeptone (50 wt\% pepton, $50 \mathrm{wt} \%$ trypton), $1 \mathrm{~g}$ NaNO3, $1 \mathrm{~g}$ KH2PO4, 0.5 g MgSO4.7H2O, and $30 \mathrm{~g}$ oil (refined olive, soybean and canola oil).

At first stage, R.oryzae grown on potato dextrose agar (PDA) slant. Erlen flask $(500 \mathrm{ml})$ containing $100 \mathrm{ml}$ of the basel medium were inoculated by aseptically transferring spores (about 106 spores) from slant, and incubated for $60-72 \mathrm{~h}$ at $35^{\circ} \mathrm{C}$ on a reciprocal shaker (150 oscillations/min) with $0.33 \mathrm{~g}$ BSPs subjected to prior sterilization. Reticulated Poly Urethane Foam (PUF) with a particle voidage of more than $97 \%$ and a pore size of 50 pores per linear inch used as BSPs. To examine the effect of BSPs size, these were cut into $6 \mathrm{~mm} \times 6 \mathrm{~mm} \times 3 \mathrm{~mm}$ cuboids and $6 \mathrm{~mm}$ cubes and added to basel medium. The R.oryzae cells became well immobilized within the BSPs as a natural result of their growth during shakeflask cultivation. After cultivation, the BSP-immobilized cells were separated from the culture broth by filtration, washed with tap water for few minutes, dried at $25^{\circ} \mathrm{C}$ temperature for 1 day, and for increase stability of lipase activity crosslinked with glutaraldehyde according to 
Ban et al method [12]. In this way the dried cells were treated with a $0.1 \%(\mathrm{v} / \mathrm{v})$ glutaraldehyde (GA) solution at $25^{\circ} \mathrm{C}$ for $1 \mathrm{~h}$ then were shaken in phosphate buffer at $4^{\circ} \mathrm{C}$ for $5 \mathrm{~min}$, washed with tap water for few minutes, and dried for $24 \mathrm{~h}$ at room temperature. Finally the GA-treated cells were used as a methanolysis catalyst.

\subsection{Lipase-catalyzed transesterification}

\subsubsection{R.oryzae whole-cell biocatalyst}

The methanolysis reactions have taken place at $35^{\circ} \mathrm{C}$ in a $50-\mathrm{ml}$ erlen flask with incubation on a reciprocal shaker (150 oscillations/min). The reaction mixture contained: 9.65 g soybean oil, $0.1 \mathrm{M}$ phosphate buffer $(\mathrm{pH} 6.8)$ in range of $0-2.5 \mathrm{ml}(0-25 \mathrm{wt} . \%$ water content by substrate weight), 0.1-1.0 g BSPs ( $1-10 \mathrm{wt} \%$ ), $0.35 \mathrm{~g}$ methanol (One molar equivalent of methanol was $0.35 \mathrm{~g}$ against $9.65 \mathrm{~g}$ soybean oil) was added stepwise to the reaction mixtures three times at 0 and different hours after start of reaction. For full convert of oil to Fatty acid methyl esters, at least three molar equivalents of methanol are necessary.

\subsubsection{Novozym 435 as a biocatalyst}

The methanolysis reaction has taken place with the immobilized lipase from Candida antarctica (Novozym 435) in the solvent-free system in a $50-\mathrm{ml}$ erlen flask at $35^{\circ} \mathrm{C}$ with incubation on a reciprocal shaker (150 oscillations/min). The reaction mixture contained 9.65 $\mathrm{g}$ soybean oil, $0.4 \mathrm{~g}$ immobilized lipase and $0.35 \mathrm{~g}$ methanol (without any distilled water) was added stepwise to the reaction mixtures three times at 0 and different hours after start of reaction.

\subsection{Analytical procedure}

The methyl esters contained in the reaction mixture was analyzed using a GC-3800CP gas chromatography (Varian Crop. Netherland) connected to a cpsil-5CB Capillary column $(0.32 \mathrm{~mm} \times 30 \mathrm{~m}$, Varian, Netherland). Samples $(200 \mu \mathrm{l})$ were taken from the reaction mixture at specified time and centrifuged at $13,000 \mathrm{rpm}$ for $5 \mathrm{~min}$ to obtain the upper layer. The methanolysis products were analyzed by capillary gas chromatography (cGC) as described below. The upper layer $(80 \mu \mathrm{l})$ and tricaprylin $(20 \mu \mathrm{l})$ which is served as the internal standard were precisely measured and mixed thoroughly in bottle with $2 \mathrm{ml}$ hexane as solvent to which a small amount of anhydrous sodium sulfate as dehydrating agent were added. A $1.0 \mu \mathrm{l}$ aliquot of the treated sample was injected into cGC. The column temperature was held at 150 ${ }^{\circ} \mathrm{C}$ for $1 \mathrm{~min}$, raised to $200^{\circ} \mathrm{C}$ at rate of $20^{\circ} \mathrm{C} / \mathrm{min}$ then raised to $207^{\circ} \mathrm{C}$ at rate of $1^{\circ} \mathrm{C} / \mathrm{min}$, finally raised to $300^{\circ} \mathrm{C}$ at rate of $30^{\circ} \mathrm{C} / \mathrm{min}$ and maintained at this temperature for $24 \mathrm{~min}$. The temperature for injector and flame ionization detector (FID) were set at 270 and $300^{\circ} \mathrm{C}$, respectively.

\section{Results and Discussion}

\subsection{Effect of BSPs size}

To examine the effect of BSPs size on methanolysis of soybean oil, PUFs cut into $6 \mathrm{~mm} \times 6 \mathrm{~mm} \times 3 \mathrm{~mm}$ cuboids and $6 \mathrm{~mm}$ cubes and added to basel medium in different erlen flasks. After preparation as mention above, these cuboids and cubes use as BSPs and 50 BSPs added to reaction mixture in present of $15 \mathrm{wt} \%$ water. Table 1 presents data on the methanolytic activity of the different size of BSP-immobilized cells after adding methanol in start of reaction. Results indicated that in case of using $6 \mathrm{~mm} \times 6 \mathrm{~mm} \times 3 \mathrm{~mm}$ immobilized BSPs methyl esters production is greater than $6 \mathrm{~mm}$ cubes BSPs because of the specific surface area 
in $6 \mathrm{~mm} \times 6 \mathrm{~mm} \times 3 \mathrm{~mm}$ BSPs is larger than other one. Therefore $6 \mathrm{~mm} \times 6 \mathrm{~mm} \times 3 \mathrm{~mm}$ immobilized BSPs was used for this research study.

Table 1. Methyl esters production (Wt\%) in different size of BSPs

\begin{tabular}{ccc}
\hline Time $(\mathrm{h})$ & $6 \mathrm{~mm} \times 6 \mathrm{~mm} \times 3 \mathrm{~mm}$ BSPs & $6 \mathrm{~mm} \times 6 \mathrm{~mm} \times 6 \mathrm{~mm}$ BSPs \\
\hline 4 & 29 & 21 \\
8 & 30 & 27 \\
12 & 32 & 31 \\
\hline
\end{tabular}

\subsection{Effect of carbon sources in basel medium}

To elucidate the effect of carbon source on cell growth and methyl esters production, various refined oils were used as carbon sources in basel medium. Figure 1 shows the time course of methanolysis catalyzed by cells grown with different carbon sources. As shown in figure 1, we can see that during whole cell catalyzed methanolysis of soybean oil for biodiesel production, the cells cultured with refined olive oil have highest activity than cells cultivated with refined soybean and canola oils. So the experiments continued using olive oil as carbon source in basel medium.

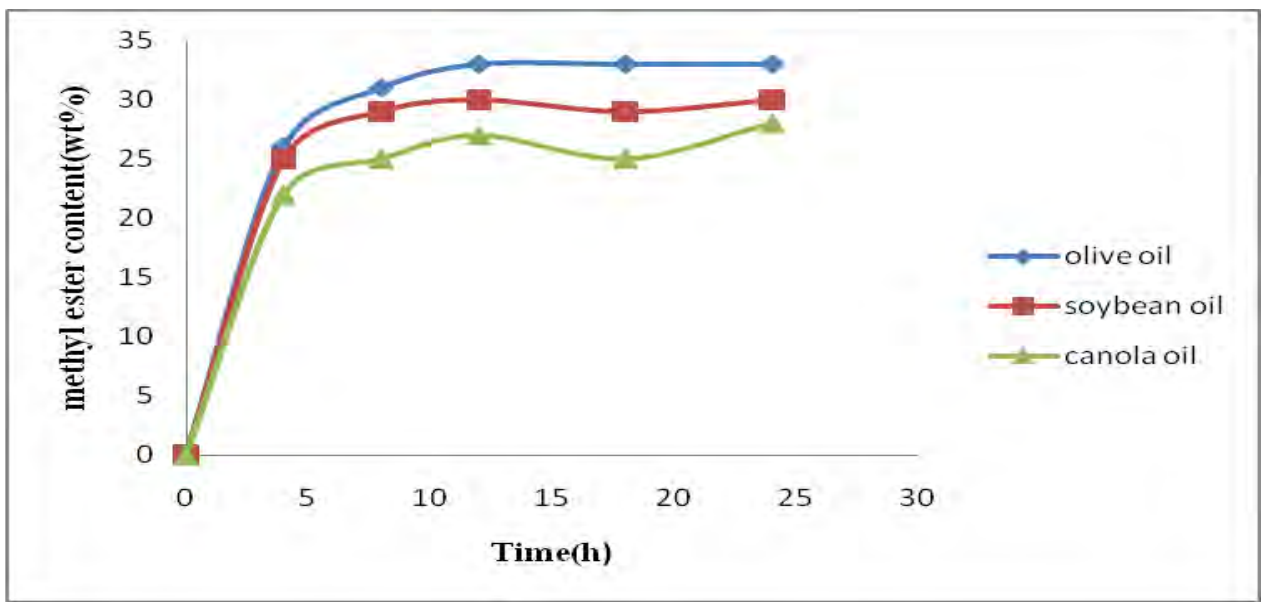

Fig. 1. Methyl ester content in methanolysis of soybean oil at different carbon source in cell cultivates (50 BSPs as a catalyst and reaction temperature at $35^{\circ} \mathrm{C}$ ).

\subsection{Effect of Emulsification of reaction mixture}

To examine the effect of emulsifying of reaction mixture over producing methyl esters, ultrasonicated and non-ultrasonicated reaction mixtures were used for methanolysis of soybean oil. Figure 2 shows the time course of methyl esters content in reaction mixture with ultrasonicated and non-ultrasonicated feed. When the reaction mixture was emulsified before methanolysis, higher lipase activity was achieved. Because the lipase catalysis occurs in the interfacial layer between the hydrophobic and hydrophilic phases, the much larger surface area of the water/oil interface seems to result in increased accessibility of the substrates to the lipase [14]. This finding suggested that emulsification of the reaction mixture has an advantageous effect on biodiesel production using whole-cell biocatalyst. Further experiments were therefore made use of emulsified substrates. 


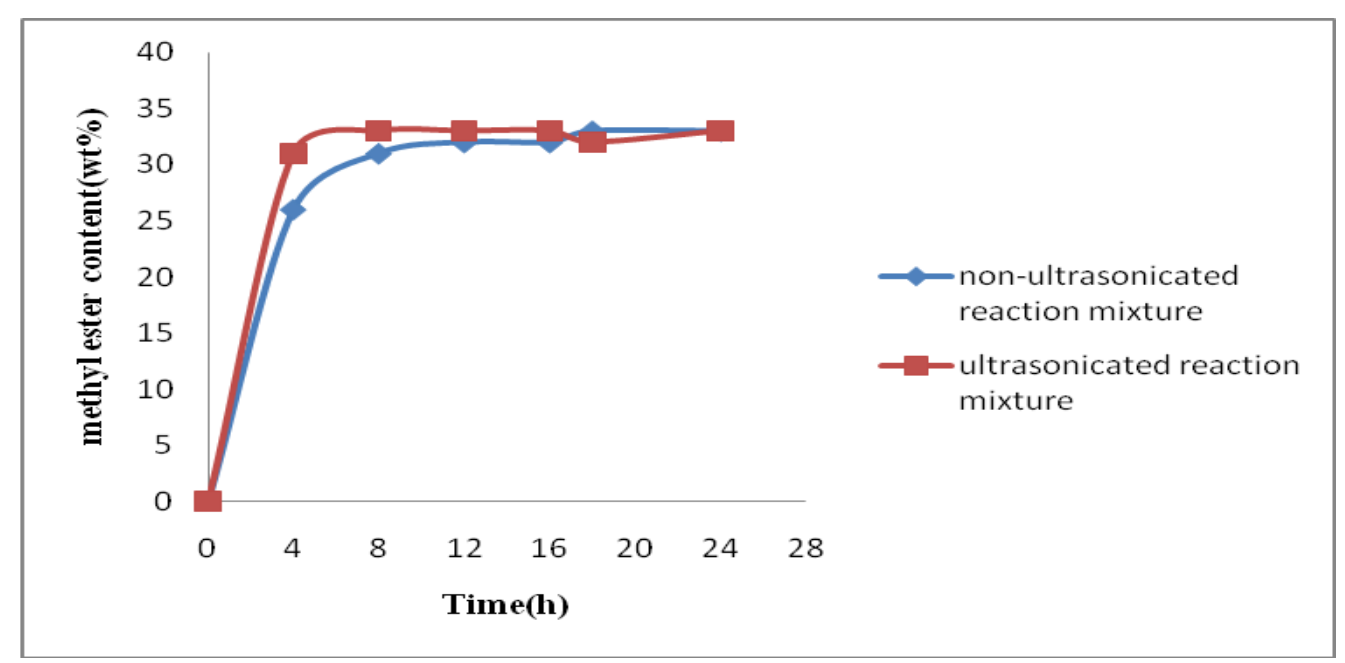

Fig. 2. Methyl ester content in methanolysis of soybean oil using ultrasonicated and nonultrasonicated reaction mixtures (50 BSPs as a catalyst and reaction temperature at $35^{\circ} \mathrm{C}$ ).

\subsection{Effect of water content and weight of biocatalyst in reaction mixture}

Figure 3 shows the activities of whole-cell biocatalyst at different water content and weight of biocatalyst. As shown in Figure 3 biodiesel achieved in the reaction mixture (after $96 \mathrm{~h}$ ) increasing with increase in water content ratio up to $15 \mathrm{wt} \%$ and decreasing after that ratio. Therefore the optimum water content for Rhizopus oryzae whole cell was obtained as $15 \%$ that confirm results indicated by ban et al [12] whereas this parameter is limited the activity of Novozym 435 for methanolysis reaction since needs closely anhydrous reaction mixture [13]. Shimada et al [14] reported that water content ( $>500 \mathrm{ppm})$ in soybean oil decreased the rate of methyl ester production using Novozym 435 as biocatalyst. An insufficient amount of water in whole-cell biocatalyst methanolysis probably results in irreversible inactivation of lipase, which may be due to denaturation of the enzyme by methanol [15]. Moreover, figure 3 shows that by increasing weight of BSPs up to $7 \mathrm{wt} \%$, methyl esters production increased and remained approximately constant up to BSPs amount of $10 \mathrm{wt} \%$.

The highest methyl ester content (after $96 \mathrm{~h}$ ); $84 \mathrm{wt} \%$, was attained when the reaction mixture contained $1.5 \mathrm{ml}$ buffer solution (15 wt\% water by substrate to weight) and $0.7 \mathrm{~g}$ BSPs (7 wt.\% BSPs by substrate to weight) which is remarkably comparable with methyl esters production using Novozym 435 as a biocatalyst. Since alkyl migration happens with intracellular lipase of immobilized cell and water can enhance cell permeability, the rate of methanolysis catalyzed by R.oryzae whole-cell biocatalyst increases in the presence of additional water. However, the excess water reduces methyl esters production due to its acts as a competitive inhibitor for lipase-catalyzed transesterification [16]. Subsequent experiments were therefore carried out using a $15 \mathrm{wt} \%$ water content and $7 \mathrm{wt} \%$ BSPs in reaction mixture. 


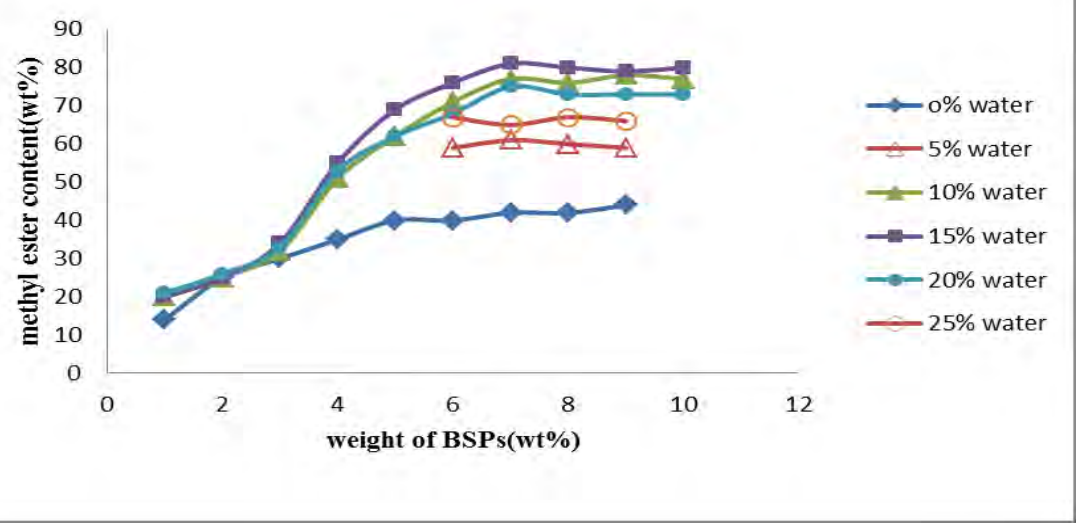

Fig. 3. Methyl ester content in methanolysis of soybean oil at different water content and weight of BSPs after $96 \mathrm{~h}$ (addition of methanol 0, 24, $48 \mathrm{~h}$ and reaction temperature at $35^{\circ} \mathrm{C}$ ).

\subsection{Time course methanolysis of soybean oil and optimization of methanol addition strategy}

In this part the authors investigated the time course methanolysis of soybean oil with stepwise additions of methanol in 0, 24 and $48 \mathrm{~h}$. Figure 4 shows the time courses of methyl esters production in different time after reaction started. As shown in figure 4, reaction continues up to 96 hours that is relatively long time while at the time such as 4 to $24 \mathrm{~h}$ and 36 to $48 \mathrm{~h}$ the methyl esters production had not much progress. The highest methyl ester content, $84 \mathrm{wt} \%$, was attained after $96 \mathrm{~h}$. In order to reduce time of reaction progress, we tried to optimize the addition strategy of methanol. So the methanol was added in different strategy as stepwise additions of methanol in 0,4 and $18 \mathrm{~h}$ after reaction. Figure 5 shows the time courses of methyl esters production using this new strategy of methanol addition. As shown in figure 5, $84 \mathrm{wt} . \%$ methyl esters production was attained after $48 \mathrm{~h}$ reaction.

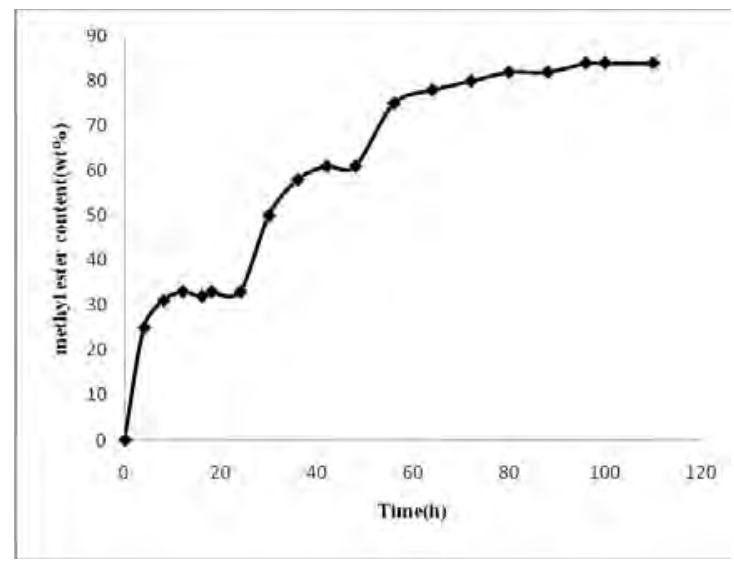

Fig. 4. Methyl ester content in methanolysis of soybean oil (addition of methanol at 0, 24 and $48 \mathrm{~h})$.

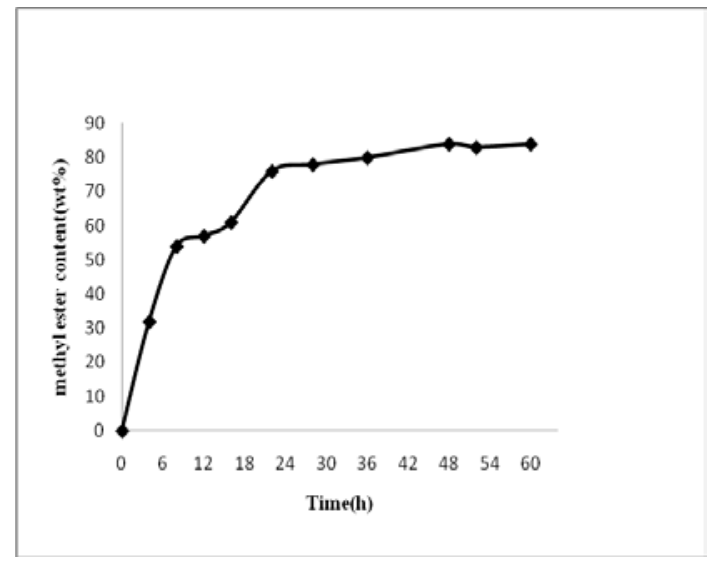

Fig. 5. Methyl ester content in methanolysis of soybean oil with new strategy (addition of methanol at 0,4 and $18 \mathrm{~h}$ ).

\subsection{Enzymatic methanolysis reaction using Novozym 435 as a biocatalyst}

For the methanolysis reaction using immobilized lipase from Candida antarctica (Novozym 435) in the solvent-free system, $0.35 \mathrm{~g}$ methanol was added stepwise to the reaction mixtures at the start of the reaction (0), 4 and $18 \mathrm{~h}$. The reaction has been carried out for $48 \mathrm{~h}$. The 
methyl ester content in the reaction mixture reached $90 \mathrm{wt} \%$ after $48 \mathrm{~h}$ that was slightly more than R.oryzae whole-cell biocatalyst.

\subsection{Stability study of BSP-immobilized cells with GA treatment and Novozym 435 for methanolysis of soybean oil}

In order to test the stability of Novozym 435 (stepwise addition of 1 molar equivalent methanol at 0, 4, and $18 \mathrm{~h}$ respectively) and GA treated R.oryzae whole-cell as biocatalyst with new methanol addition strategy (stepwise addition of 1 molar equivalent at 0,4 , and $18 \mathrm{~h}$ respectively), both the biocatalysts were separated from the reaction mixture by filtration and directly used for the next cycle. The time of methanolysis using R.oryzae whole-cell and Novozym 435 are kept constant at $48 \mathrm{~h}$ for each reaction cycle (as shown in figure 6). It was found that there was almost no significant decrease in methyl esters production even after 5 batches cycle in both lipases and both can be used for repeated batches cycles.

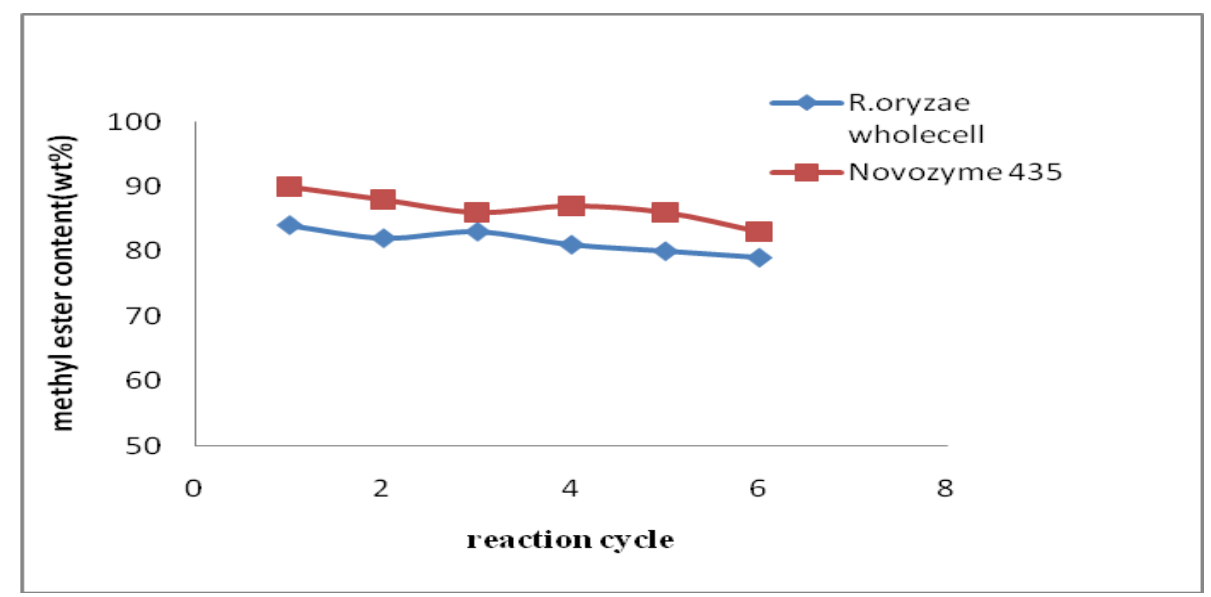

Fig. 6. Methyl ester content in methanolysis of soybean oil using GA treated R.oryzae whole-cell and Novozym 435 as biocatalyst for repeated reaction cycles (addition of methanol in 0, 4 and $18 \mathrm{~h}$ ).

\section{Conclusions}

This work deals with the enzymatic transesterification of refined soybean oil using Rhizopus Oryzae (ATCC 9374) whole-cell biocatalyst and Novozym 435 (Commercial immobilized lipase from Candida antarctica) as biocatalyst. In the case of using whole-cell biocatalyst effect of BSPs size, carbon sources in basel medium, emulsification of reaction mixture, water content and weight of biocatalyst in reaction mixture on yield of biodiesel production were investigated. The maximum methyl esters content in the reaction mixture reaches $84 \mathrm{wt} \%$ using Rhizopus oryzae whole-cell biocatalyst in optimum condition of reaction after $48 \mathrm{~h}$ which is remarkably comparable with biodiesel yield $90 \mathrm{wt} \%$ of Novozym 435. The optimum water content for Rhizopus oryzae was obtained as $15 \%$ whereas this parameter is limited the activity of Novozym 435 for methanolysis. Both the lipases can be used for repeated batches cycles. These findings indicate that, given the simplicity of the lipase production process and the long-term stability of lipase activity, the use of whole-cell biocatalysts immobilized within BSPs and treated with GA solution suggest a favorable means of biodiesel fuel production for industrial application.

\section{References}

[1] M. S. Antczak, A. Kubiak, T. Antczak, S. Bielecki, Enzymatic biodiesel synthesis - Key factors affecting efficiency of the process, Renewable Energy 34, 2009, 1185-1194. 
[2] H. Fukuda, A. Kondo, H. Noda, Biodiesel fuel production by transesterification of oils, J. Biosci. Bioeng. 92, 5, 2001, 405-416.

[3] P. S. Bisen, B. S. Sanodiya, G. S. Thakur, R. K. Baghel, G. B. K. S. Prasad, Biodiesel production with special emphasis on lipase-catalyzed transesterification, Biotechnology Letters 32, 2010, 8, 1019-1030.

[4] H. Fukuda, S. Hama, S. Tamalampudi and H. Noda, Whole-cell biocatalysts for biodiesel fuel production, Trend in biotechnology 26, 2008, 12, 668-673.

[5] A. Robles-Medina, P.A. González-Moreno, L. Esteban-Cerdán, E. Molina-Grima, Biocatalysis: Towards ever greener biodiesel production, Biotechnology Advances 27, 2009, 398-408.

[6] Y. Shimada, Y.Watanabe, T. Samukawa, A. Sugihara, H. Noda, H. Fukuda, Y. Tominaga, Conversion of vegetable oil to biodiesel using immobilized Candida antarctica lipase, J. Am. Oil Chem. Soc. 76, 1999, 789-793.

[7] Y. Xu, W. Du, D. Liu, J. Zeng, A novel enzymatic route for biodiesel production from renewable oils in a solvent-free medium, Biotechnology Letters 25, 2003, 1239-1241.

[8] W. Du, Y. Xu, D. Liu, J. Zeng, Comparative study on lipase-catalyzed transformation of soybean oil for biodiesel production with different acyl acceptors, J. Mol. Catal. B: Enzym. 30, 2004, 125-129.

[9] S. V. Ranganathan, S. L. Narasimhan, K. Muthukumar, An overview of enzymatic production of biodiesel”, Bioresource Technology 99, 2008, 3975-3981.

[10] Ting Sun, Wei Du and Dehua Liu, Prospective and impacts of whole cell mediated alcoholysis of renewable oils for biodiesel production, Biofuels, Bioprod. Bioref. 3, 2009, 633-639.

[11]K. Ban, S. Hama, K. Nishizuka, M. Kaieda, T. Matsumoto, A. Kondo , H. Noda, H. Fukuda, Repeated use of whole-cell biocatalysts immobilized within biomass support particles for biodiesel fuel production, Journal of Molecular Catalysis B: Enzymatic 17, 2002, 157-165.

[12] K. Ban, M. Kaieda, T. Matsumoto, A. Kondo, H. Fukudac, Whole cell biocatalyst for biodiesel fuel production utilizing Rhizopus oryzae cells immobilized within biomass support particles, Biochemical Engineering Journal 8, 2001, 39-43.

[13] S. Tamalampudi, M. R. Talukder, S. Hama, T. Numata, A. Kondo, H. Fukuda, Enzymatic production of biodiesel from Jatropha oil: A comparative study of immobilized-whole cell and commercial lipases as a biocatalyst, Biochemical Engineering Journal 39, 2008, 185-189.

[14] Y. Shimada, Y. Watanabe, A. Sugihara, Y. Tominaga, Enzymatic alcoholysis for biodiesel fuel production and application of the reaction to oil processing, J. Mol. Catal. B: Enzym. 76, 2002, 133-142.

[15] S. Hama, H. Yamaji, T. Fukumizu, T. Numata, S. Tamalampudi , A. Kondo, H. Noda, H. Fukuda, Biodiesel-fuel production in a packed-bed reactor using lipase-producing Rhizopus oryzae cells immobilized within biomass support particles, Biochemical Engineering Journal 34, 2007, 273-278.

[16] R.H. Valivety, G.A. Johnston, C.J. Suckling, P.J. Halling, Solvent effects on biocatalysis in organic systems: equilibrium position and rates of lipase-catalysed esterification, Biotechnol. Bioeng. 38, 1991, 1137-1143. 